\title{
DIGITALIZATION, REGIONAL COMPETITIVENESS AND THE GOVERNMENTS OF THE FUTURE
}

\author{
Bence Zuti \\ University of Szeged Doctoral School of Economics \\ E-mail: zuti.bence@gmail.com
}

\begin{abstract}
Nowadays digitalization is one of the key global drivers of change. It acts as a catalyst for transition in all aspects of our lives. With this transition occurring at present, the traditional models of our society and economy are being challenged on a daily basis. Solutions provided by technology are becoming more accessible and commonly implemented in everyday practices. The presence of innovative companies, SMEs and R\&D activities are considered crucial elements of the competitiveness of a certain region; however, it is worth to highlight that besides these elements, the role of the government and the public sector should also be accentuated. The competitiveness of the region can also be improved by focusing on providing redefined services tailored to meet the needs of citizens of a new, digital era. With digitalization, there is an opportunity for governments to be more in terms of inclusiveness, transparency and trustworthiness, hence operating in a more effective way than before. The goal of the paper is to systematize the connections between regional competitiveness and governments of the digital age.
\end{abstract}

Keywords: Regional competitiveness, digitalization, globalization, governments.

\section{A Brief Description of the Digital Age}

With recent advancements in technology, digitalization is one of the key global drivers of change. It acts as a catalyst for transition in all aspects of our lives. With this transition occurring at present, the traditional models of our society and economy are being challenged on a daily basis. Solutions provided by technology are becoming more accessible and commonly implemented in everyday practices, which enables competition on a global level, meaning not only for multinational organizations, but individuals can be involved in social and activities on a global scale (Schwab 2017, EC 2017, Manyika et al. 2016). 
The environment that is currently surrounding our society can be defined as a smart, connected, complex and interactive environment, which is rapidly and radically changing (Kovács 2017a, Kovács 2017b, OECD 2017, Schwab 2017, Yoon 2017, Manyika et al. 2016, Lee - Vivarelli 2006). The trend highlighted by Lengyel (2010) is true today as well: The potential of economies and society as a whole is decreasing on a national level, while parallel, the role of subnational territories, like regions, cities and individual elements of society experience as increase in significance.

Disruptive ideas, business models, innovations have become an everyday phenomenon, so there is an increasing need in understanding the background motives of the change we experience. We need to study the attitudes present in the economy and society and with the data collected and information is created, we need to answer the question on how we can remain competitive in a rapidly changing global environment (WEF 2016a).

\section{The Importance of Regional Competitiveness in the $21^{\text {st }}$ Century}

Even after decades of research within the topic among a wide range of experts from academics to policymakers and consultants, regional competitiveness remains a popular topic of discussion (IMD 2017, WEF 2016a, WEF 2016b, UN-HABITAT 2013, Dijkstra - Annoni Kozovska 2011, Lengyel 2010).

By examining the validity and definition of regional competitiveness, it can be grouped into 2 large categories (Huggins et al. 2014, Lengyel 2010). The first group interprets competitiveness as a definition valid only in case of enterprises and on a strictly business and economic level (Lengyel 2010). The second group argues that competitiveness can be used for territorial units as well, as one result of globalization is that nations, regions, local territorial units compete for resources, talent and capital on a global scale (Lengyel 2010). This paper accepts the latter as a foundation for further discussion.

Several attempts were made to define competitiveness (Annoni - Dijkstra - Gargano 2017, WEF 2016b, Atkinson 2013). However, the most commonly known definition is the standard definition, determined by the EC (1999, p. 75): “Competitiveness is defined as the ability of a region to generate, while being exposed to external competition, relatively high income and employment levels. In other words, for a region to be competitive, it is important to ensure both quality and quantity of jobs".

What is similar in these definitions is the fact that they all more or less highlight the importance of productivity, high levels of income, employment and the presence of attractive and 
sustainable economic and social environments. Due to this Lengyel and Rechnitzer (2013) and also Huggins et al (2014) highlight that competitiveness is a set of hard and soft dimensions. These dimensions influence each other and are deeply interconnected.

Until a recent report published by IMD (2017), the definition of competitiveness was not embedded in a digital context. The IMD (2017, p. 19.) defines digital competitiveness as: “... the capacity of an economy to adopt and explore digital technologies leading to the transformation in government practices, business models and society in general. In this way, firms increase the opportunities to strengthen future value creation". This definition recognizes competitiveness as an ability rather than a condition and also puts emphasis on proactivity and sustainable long-term value creation (IMD 2017). With trust as a core element, the integration of digital technologies in the services provided by the public sector, cost-effective and contemporary ways of working can be designed (Chakravorti - Chaturvedi 2017, Chakravorti - Bhalla-Chaturvedi 2017, IMD 2017, TU 2017, Loucks et al. 2016, WEF 2016b, Hage 1999). It is widely accepted that social capital and institutions as a factor are contributors to the competitiveness of regions, as this serves as a provider of physical infrastructures and immaterial assets. Not only the efficiency of these institutions is key, but the connections between them also have a crucial role. Connections among actors of the government, industry and society determine the level and state of cultural patterns, behaviours and attitudes within the region. The regional culture of a region affects how a region handles changes and the evolution of economic structures and how actors connect and cooperate with and inform each other (Lengyel 2010, Lengyel 2016).

\section{Governments of the Future}

In a fast-paced world, where "digitalization" or "going digital" are fundamental buzzwords, it is self-apparent that governments will also need to take action and take part in the journey towards creating a foundation that is driven by the opportunities brought by the digital age. While this part is clearly evident, the question of "How?" remains completely open for these institutions (Janowski 2015). The multidisciplinary research of attitudes, the mapping of sources and opportunities, the analysis of benchmark and learning from other governments' experiences will have a key role in the forthcoming digitalization of public institutions. As the public sector of each territorial unit is different, we surely cannot talk about the existence of universal standards for digitalizing a government, however we can emphasize comprehensive factors that can be taken into consideration (Janowski 2015). 
Kloes, Piat and Ghislain (2015, p. 5.) define digital governments as follows: "Digital government refers to the production of and access of data, services and content, sourced and distributed across the digital ecosystem, to create public value."

The idea behind the digitalization of governments is the vision of supporting the processes operating within these institutions, while also enhancing efficiency and quality of the services provided by the public sector. In case digital aspects are integrated into governments, the everyday link between the public sector and society will be strengthened, as interactions can be immediate, more user-friendly and even more transparent in an economically cost-effective way (EC 2016). Currently, within the European Union there is a strong focus on delivering digital solutions to further enhance the capabilities and opportunities provided by governments. These capabilities and opportunities should be aligned with the expectations and beneficial outcomes seeked by the civil and business sectors (EC 2016, PwC 2013). The time has come for the public sector to demonstrate their adaptiveness and contemporary thinking in the digital and information age. This demonstration will require a shift in the core mindset of these institutions. The shift will include giving citizens more control in governance, the creation and maintenance of purpose-driven organizational networks, where collaboration and trust among parties are central values (PwC 2013). A dynamic shift like this will require proactive thinking and accurate leadership that supports the investment in human capital and drives behavioural change (Carrasco - Goss 2014).

The EC (2016, p. 4.) highlights 7 principles as key options to be followed when creating the government of the future, these principles are as follows:

Governments of the future should operate digital by default. This means that public institutions should make an effort to deliver their services digitally, where possible. While this will be considered the preferred way, governments should not forget about those, who choose to be disconnected and preferring traditional office routines (EC 2016).

The once only principle proposes that public institutions obtain data once from citizens and actors of the economic sector. The may re-use of the once collected data in case they are allowed to do so, while remaining fully aligned with fundamental data protection regulations (EC 2016). Inclusiveness and accessibility focuses on the construction of such services that can be accessed by a wide range of people of any demographic characteristic. (EC 2016)

Openness and transparency focuses on the secure sharing of data among institutions in order to enable the correction and the full control of data from the perspective of the society and industry. The analysis of data should positively contribute to the quality of services delivered 
by digitalized public institutions. Advanced analysis will lead to the creation and design of more efficient services, based on expectations (Coleman - Foreman 2016, EC 2016).

The cross-border by default principle means that the digital public services provided should be available throughout all regions within a territory, so the accessibility of services is uniform (EC 2016).

The interoperability by default principle aims for service design that works coherently among institutions supporting the movement of data and digital services. This can be realized for example with cost-efficient services, the deployment of cloud services or harnessing the opportunities of the Internet of Things (Coleman - Foreman 2016, EC 2016).

The trustworthiness and security principle targets cyber- and data security initiatives, so personal data is handled in a secure way and the protection of privacy is an integral part of the digital service design. As people often use smart devices in their everyday lives, applications, services and data provided by the governments should be accessed by the citizens or actors of the economic sector (Coleman - Foreman 2016, EC 2016).

Implementing these principles in design of services provided by digital governments will be a truly challenging task which will require specialization, proactivity and a technology-oriented mindset. But still, going digital is an act that needs to be swiftly considered by governments, as the digital natives of the future are more and more attracted to technology and the opportunities smart devices and applications provide (Kloes - Piat - Ghislain 2015).

\section{Conclusion}

It is evident today that digitalization is one of the most significant driver of change on our globe. By acting as a catalyst of change, we can experience several shifts in how we live our everyday lives. New solutions and business model contribute to the creation and design of accessible, cost-efficient solutions and practices. In this transition, governments can be facilitators of change related to infrastructure, legal aspects and behavior. Key principles like inclusiveness, transparency and trustworthiness serve as fundamentals of enhancing regional competitiveness. In the digital and information age, an open and multidisciplinary discussion is necessary among business professionals, policymakers, and academia, as the study highlighted the complexity of government relations is huge. 


\section{Acknowledgements}

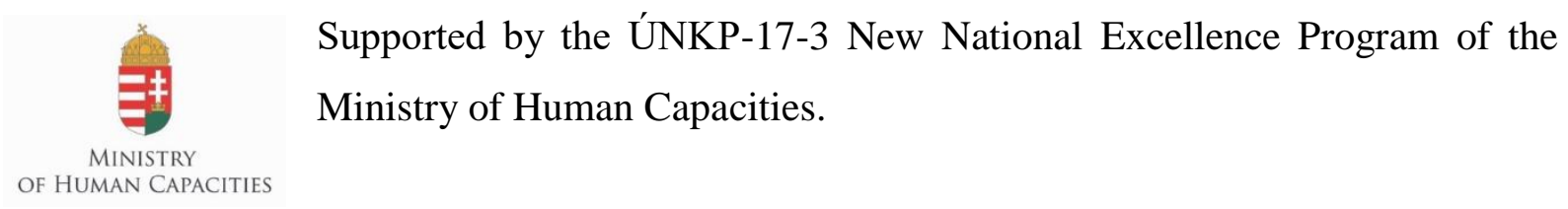

\section{References}

1. Annoni, P. - Dijkstra, L. - Gargano, N. (2017): The EU Regional Competitiveness Index 2016. Working Paper 02/2017. European Commission, Brussels.

2. Atkinson, R. D. (2013): Competitiveness, Innovation and Productivity: Clearing Up the Confusion. The Information Technology and Innovation Foundation, Washington, DC.

3. Carrasco, M. - Goss, P. (2014): Digital Government. Turning the Rhetoric into Reality. The Boston Consulting Group.

4. Chakravorti, B. - Chaturvedi, R. S. (2017): Digital Planet 2017. How Competitiveness and Trust in Digital Economies Vary Across the World. The Fletcher School, Tufts University. Medford, MA.

5. Chakravorti, B - Bhalla, A. - Chaturvedi, R. S. (2017): 60 Countries' Digital Competitiveness, Indexed. Harvard Business Review Digital Article,

6. Coleman, C. - Forman, M. (2016): Seven Pillars for Becoming a Digital Government Organization. The Path to Digital Transformation and Innovation for Government and Citizen Services. A Digital Government Series by Unisys Corporation. Blue Bell, PA.

7. Dijkstra, L. - Annoni, P. -Kozovska, K. (2011): New Regional Competitiveness Index: Theory, Methods and Findings. Working Paper 02/2011. European Commission, Brussels.

8. EC (2016): EU eGovernment Action Plan 2016-2020. Accelerating the Digital Transformation of Government. Communication from the Commission to the Parliament, the Council, the European Economic and Social Committee and the Committee of the Regions. European Commission, Brussels.

9. EC (2017): Reflection Paper on Harnessing Globalization. European Commission, Brussels.

10. Hage, J. T. (1999). Organizational Innovation and Organizational Change. Annual Review of Sociology, 25, 597-622. 
11. Huggins, R. - Izushi, H. - Prokop, D. - Thompson, P. (2014): Regional competitiveness, economic growth and stages of development. Proceedings of Rijeka School of Economics $32,255-283$.

12. IMD (2017): IMD World Digital Competitiveness Ranking 2017. International Institute for Management Development World Competitiveness Center, Lausanne.

13. Janowski, T. (2015): Digital government evolution: From transformation to contextualization. Government Information Quarterly, 32, pp. 221-236.

14. Kovács, O. (2017a): Az ipar 4.0 komplexitása - I. Közgazdasági Szemle, 56, 823-851.

15. Kovács, O. (2017b): Az ipar 4.0 komplexitása - II. Közgazdasági Szemle, 56, 970-987.

16. Manyika, J. - Lund, S. - Bughin, J. - Woetzel, J. - Stamenov, K. - Dhingra, D. (2016): Digital Globalization: The New Era of Global Flows. McKinsey Global Institute, New York, NY.

17. Kloes, G. - Piat, O. - Ghislain, L. S. (2015): Digitalization for Governments and Ecosystems. Deloitte Luxembourg, Luxembourg.

18. Lee, E. - Vivarelli, M. (2006) The Social Impact of Globalization in the Developing Countries. Discussion Paper No. 1925. Institute for the Study of Labor, Bonn.

19. Lengyel, I. (2009): Bottom-up Regional Economic Development: Competition, Competitiveness and Clusters. In Bajmócy Z. - Lnegyel I. (eds.): Regional Competitiveness, Innovation and Environment, JATEPress, Szeged. 13-38.

20. Lengyel, I. (2010): Regionális gazdaságfejlesztés. Versenyképesség, klaszterek és alulról szerveződő stratégiák. Akadémiai Kiadó, Budapest.

21. Lengyel, I. (2016): A megyék versenyképességének néhány összefüggése a megújult piramismodell alapján. In: Lengyel, I. - Nagy, B. (eds.): Térségek versenyképessége, intelligens szakosodása és újraiparosodása. JATEPress, Szeged. 143-161.

22. Lengyel, I. - Rechnitzer J. (2013): Drivers of Competitiveness in the Central European Countries. Transition Studies Review 20, 421-435.

23. Loucks, J. - Macaulay, J. - Noronha, A. -Wade, M. (2016): Digital Vortex: How Today's Market Leaders Can Beat Disruptive Competitors at Their Own Game. DBT Center Press, Lausanne.

24. OECD (2017): Making Globalization Work: Better Lives for All. OECD Publishing, Paris.

25. Schwab, K. (2017): The Fourth Industrial Revolution. The Crown Publishing Group, New York, NY.

26. TU (2017): The Digital Evolution Index 2017. The Fletcher School, Tufts University. Medford, MA. 
27. UN-HABITAT (2013): The Competitiveness of Cities. The Global Urban Economic Dialogue Series. UN-HABITAT, Nairobi.

28. WEF (2016a): Digital Transformation of Industries: Digital Consumption. World Economic Forum, Geneva.

29. WEF (2016b): The Global Competitiveness Report 2016-2017. World Economic Forum, Geneva.

30. Yoon, D. (2017): What We Need to Prepare for the Fourth Industrial Revolution. Healthcare Informatics Research, 23, 75-76. 